The Editor-in-Chief's recommendation of this issue's article to readers;

\title{
INJURIES IN THE MAXILLOFACIAL COMPLEX AND ASSOCIATED FACTORS IN BRAZILIAN VICTIMS OF VIOLENCE: A CROSS-SECTIONAL STUDY
}

I am pleased to inform you that I have chosen this article by Laureno et al. ${ }^{1}$ as Editor's Choice for first issue of 2019.

Violence is a major and ever-mounting problem throughout the world. The maxillofacial region is exposed to injuries due to its easily reachable, more prominent and unprotected location. Maxillofacial injuries can cause serious health problems, post-traumatic psychological effects or even death. To be informed about the prevalence of jaw-face injuries in victims of violence is important to evaluate the needs of health services and to minimize the consequences of aggression.

This article shows that physical aggression is the most frequent type of violence, with high occurrence of head and face injuries. Face injuries showed association with gender and number of lesions, both being more frequent among women.

Happy readings and have a great year with increasing academic interest in 2019 !

Assoc. Prof. Burak Buldur

Editor-in-Chief

\section{REFERENCE}

1. Laureno ICC, Farias L, De Souza G, Alencar A, Cavalcanti AFC, De Alencar CRB, Cavalcanti AL. Injuries in The Maxillofacial Complex and Associated Factors in Brazilian Victims of Violence: A CrossSectional Study. Cumhuriyet Dent J 2019;22:1:3-10. 